,$\therefore$.

TECHNICAL DIVISION

SAVANNAH RIVER LABORATORY

,

$\underline{M} \underline{\mathrm{E}} \underline{\mathrm{M}} \underline{\mathrm{O}} \underline{\mathrm{R}} \underline{\mathrm{A}} \underline{\mathrm{N}} \underline{\mathrm{D}} \underline{\mathrm{U}} \underline{\mathrm{M}}$
Keywords: Burial Ground

Water Balance

Hydrology

Groundwater

TO: E. L. ALBENESIUS, 773-A

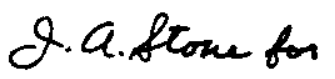

EROM: J. E. HUBBARD*
DPST $-85-958$

ACe. No, $190<37$

cc: W. R. Stevens, III, 7t3-A

I. W. Marine, 773-42A

D. E. Gordon, 773-42A

J. A. Stone, 773-41A

H. F. Sturm, Jr., 773-A

LLW Group (7)

BGT Group (3)

SRL Records (4), 773-A

January 9,1986

AN UPDATE ON THE SRP BURIAL GROUND

AREA WATER BALANCE AND HYDROLOGY

\title{
INTRODUCTION AND SUMMARY
}

A water budget for the burial ground area prepared by Hubbard and Emsliel concluded that about 15 inches, almost one-third of the average annual precipitation, normally infiltrates the land surface and recharges the groundwater. Also, evapotranspiration was estimated to average 30 inches annually, and runoff from the 1 and surface was estimated as 1 to 3 inches.

More information has become available recently from lysimeter studies, climatic stations, groundwater studies, and stream discharge measurements. These additional data generally support the conclusions above with some modifications.

The type of vegetation cover on the land surface affects the site hydrology and water budget components of evapotranspiration and groundwater recharge. The lysimeter studies indicate that about

* Faculty Research Participant, Summer 1985. Permanent address: Department of the Earth Sciences, State University of New York, College at Brockport, Brockport, NY 14420 
12 inches more water is lost annually to the atmosphere by evapotranspiration with deep-rooted pine trees present than in areas where bare soil or shallow-rooted grass cover occur. Therefore, recharge in the burial ground area may differ from that with similar soils in forested areas of the Savannah River Plant.

study of the hydrologic properties of soils in the burial ground area indicates that infiltration rates for the soils generally are relatively high, exceeding one inch per hour. Runoff as overland flow tends to occur only with intense rainfall events of 1 inch or more. The soil-water characteristic curves are representative of relatively coarse-textured soils.

\section{RESULTS}

The values expressed here are "best estimates" based on the lysimeter studies, evaporation pan climatic data, and studies by other investigators. Estimates of the water budget, expressed as annual normals representative of the burial ground site, are:

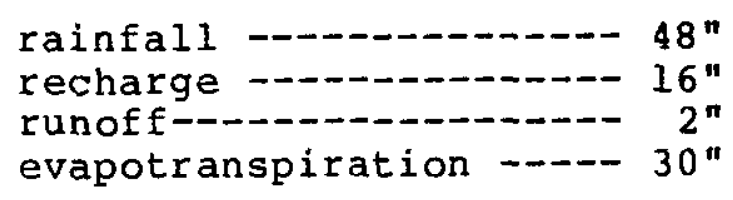

In forested areas near the burial ground, evapotranspiration is estimated to be about 40 inches annually, and therefore recharge to the water table is about 6 inches. About one-half of the recharge at the burial ground normally flows below the "tan clay."

Infiltration rates for burial ground soils are generally I inch per hour or greater. Surface runoff occurs infrequently, in intense rainstorms, and is unlikely to exceed 3 inches annually because of the relatively low topography, permeable soils, and vegetative cover over much of the burial ground. Problems of erosion from surface runoff tend to be limited to the exposed bare soils with a substantial clay content now located about the working area of active trenches.

\section{DISCUSSION}

\section{Water Budget Estimates From Wasteform Lysimeter Data}

Hubbard and Emsliel observed that an analysis of records of water volumes collected in Defense Waste Lysimeter studies compared well with other analysis techniques used for water budget estimates. 
The lysimeters, filled with soils from the burial ground trenches, are used for studies of leaching and waste migration. The volumes of percolate water pumped from the lysimeter sumps are measured regularly. Subtraction of the percolate volumes from the measured rainfall provided an estimate of the amounts of water lost to the atmosphere by evapotranspiration. Two additional years of lysimeter and rainfall data provided a larger sample of hydrologic processes. Records of the lysimeter studies from 1980 through 1984 provided by Emslie were used in most of this analysis.

The percolate water, collected from sumps 10 feet below ground surface, represents rainfall which infiltrated the soils of the tank lysimeters and flowed downward. The cylindrical lysimeters used in the study are exposed to normal rainfall and pumped regularly. The diameters are six or ten feet. There is no runoff because the rims of the lysimeters extend above the surface. The percolate volume thus represents the sum of runoff and groundwater recharge. Periods of three months, generally corresponding to seasons of the year, were used in the water budget analysis. January through March is called winter in this analysis, April through June is called Spring, etc. Evapotranspiration was calculated as the differnce between rainfall and the percolate volume during during each three month period.

The analysis of the lysimeter data is shown in Table 1. Most of the annual recharge occurs in Winter and Spring periods. This is caused by the relatively high rainfall and the low amounts of evapotranspiration characteristic of these cooler seasons. Recharge is generally lower in Summer because of high evapotranspiration. Recharge is lower in Fall because of lower rainfall in that season.

Table 2 presents a climatic monthly evapotranspiration estimate typical of the region, based on data recorded at Blackville, South Carolina. The 34 inches estimated annual total is distributed as $7.4,9.9,10.8$, and 6.2 inches in winter, Spring, summer, and Fall. The pan coefficients used with the Blackville, South Carolina data were developed for agricultural watersheds in the coastal plains near Tifton, Georgia, a region with somewhat similar topography, soils, and climate. Reported measurements of evapotranspiration in this region are few. Table 2 likely represents a better seasonal distribution of evapotranspiration amounts than does Table 1 , and the higher total in Table 2 is more characteristic of areas of agricultural land.

The estimates of recharge and evapotranspiration in Table 1 are based on the water which reaches the lysimeter sump. The exact nature of the water movement as saturated and unsaturated flow in the soils is not well understood at this time. The time lag in its 
movement from the surface to the lysimeter sumps reflects storage within the soil pores as well as transport processes. Some of the percolate collected as recharge may have infiltrated months before reaching the sump. Yet, after large rainfall events, water collects in the sumps in a few days. A simple tracer study has been started in a lysimeter to provide better understanding of processes involved.

\section{The Time Variability of Recharge, Rainfall,} and Evapotranspiration

Table 1 also indicates the relative variability for years and seasons. The coefficient of variability (C.V.) is the percentage ratio of the standard deviation to the mean. The $C . V$. value is greatest for recharge, 238. Rainfall and evapotranspiration both have a C.V. of 168. Seasonal variability is much greater than annual variability. Recharge has C.V. values exceeding 608 for spring, Summer, and Fall seasons.

The effect on the amount of recharge during the year, related to the time distribution of rainfall, is shown in Table 1 for 1983 and 1984 , years of relatively equal annual rainfall. The greater than normal winter and Spring rainfall in 1984 resulted in 22 inches of recharge for that period. This was more than the total recharge of 1983 or of any other year in which rainfall amounts were more evenly distributed. But the period of low rainfall in Fall 1984 resulted in less recharge and less evapotranspiration than in 1983. Some lysimeters contained no percolate water at all in Fall 1984.

The elevation of the water table below the burial ground appears to have a time lag of about six months with respect to periods of excess rainfall. A relationship between recharge and the response of water table well $\mathrm{C}-21$ is shown in Figure 1 . To construct the figure, the assumptions were made that the yearly recharge is 16 inches and that recharge of 4 inches each quarter would maintain the water table. Recharge exceeding that amount would cause the water table to rise, and recharge less than 4 inches would cause it to fall. The cumulative net recharge from 1980 through Spring 1985 and the relative water table elevation are plotted in the figure to show an association.

\section{Problems with Using the Lysimeters for Water Budget Estimates}

The hydraulic performance of the Defense Waste Lysimeters was examined by Emslie.2 The statistical analysis pointed out problems with lysimeter data associated with leaks in the systems and pump failure. Therefore, only unsaturated six- and ten-foot lysimeters at the site were used for water budget estimation. The six-foot lysimeters used in updating 1983 and 1984 data are 
1ysimeters \#1, \#6, \#8, \#11, \#14,\#18,\#32, and \#38. Ten-foot lysimeters \#10 and \#35 also provided representative data for the burial ground study. None of the lysimeters has vegetative cover as dense as the grass cover at 643-G.

4. The Effect of Vegetation Type on Evapotranspiration and Recharge

Some of the unsaturated ten-foot diameter lysimeters support the growth of the pine trees 10 to 14 feet high. Examination of the percolate volumes from these lysimeters suggests that the deeprooted pines transpired at least 12 inches more water than the sparse cover of bahia grass and herbacious plants in most lysimeters.

Figure 2 shows the cumulative curves of 1984 rainfall and percolate volumes for lysimeters with and without pines present. The 1983 data also show a difference of about 12 inches. The increased transpiration from areas where more deeply rooted trees are present is expected to result in considerably less groundwater recharge.

\section{The Results of other Studies of Water Budgets} in the SRP Region

MCQueen Branch watershed, located a short distance northeast of the burial grounds, was studied by Parizek and Root. 3 A weir was installed for stream discharge measurement. Surface runoff events were separated from base flow of the stream by hydrograph analysis. Although the McQueen Branch watershed differs from the burial ground area in some respects, estimates (Table 3 ) of 30 inches of evapotranspiration, 3 inches of surface runoff, and most of the remainder annually as recharge, are generally in agreement with those made by Hubbard and Emslie.l

The McQueen Branch study provides additional information about groundwater movement in the Barnwell Formation above and the McBean Formation below the "tan clay." An estimated annual flow of 7 inches above the "tan clay" and 8 inches below the "tan clay" may be inferred. This is in reasonable agreement with the estimate for the burial ground area reported by Hubbard and Emslie. 1

Denehy and McMahon 4 have completed a lysimeter study at the Chem-Nuclear waste disposal site in Barnwell, South Carolina, to be published by the U. S. Geological Survey. These data, taken from July 1983 through June 1984, showed that almost all of the recharge occurred in winter and Spring 1984. The measurements show almost no runoff, 15 inches of recharge, and 30 inches of evapotranspiration annualiy. $V$. Ischamura of Chem-Nuclear, has begun a new water balance study at the Barnwell site (personal communication). 
6. An Attempt to Analyze Hydrogeologic

Control of Stream Discharges

The hydrologeologic stratigraphy described by Hubbard and Emsliel includes the Barnwell Eormation, overlying and meeting an aquitard, the "tan clay," at an elevation 200 feet above sea level. The McBean Formation, the next layer in the sequence of formations, is similarly bounded 130 feet above sea level by another aquitard, the "green clay". The Congaree Formation is the next groundwater zone below the "green clay".

Table 4 presents a comparison of discharges of streams near the burial ground. Measurements reported by the U. S. Geological Survey ${ }^{5}$ are compared with those made of McQueen Branch by Parizek and Root ${ }^{3}$ from April 1983 through March 1984. The discharges and rainfall amounts are expressed in inches. The stream flow reflects surface runoff and discharges from groundwater zones.

The U. S. Geological Survey stream gage for Four Mile Creek at Road 4 is assumed to be located just above the "tan clay." Values representing the "natural behavior" of the creek were calculated by subtracting discharges at two $H$ Area gages from the Road 4 gage. McQueen Branch includes flows from below the "tan clay" in the McBean Formation, according to Parizek and Root. 3 Table 4 shows that McQueen Branch has a greater annual streamflow yield than Four Mile Creek.

Similarly, Upper Three Runs at Road $A$, where the gage is assumed to be below the "green clay", yields greater streamflow than at the Road $C$ gage above the aquitard. This indicates base flows from Congaree Formation groundwater discharge. Further analyses of gaged streams may provide more quantitative understanding of groundwater-surface water interaction near the burial ground site.

\section{Runoff Studies in the Burial Ground Area}

Runoff estimates were made using daily precipitation and soils information, by a method used by the $U$. $S$. Department of Agriculture Research Service and described by Lane. 6 The daily precipitation data were taken from 200-F Area, and soils information descriptive of the site was used to determine a curve number (CN) representing the hydrologic soil group present. A CN of 72 was selected. This refers to Soil Group A, characterized by bare soils with infiltration rates exceeding 0.30 inches per hour, which would be a conservative representation of the active burial ground. $A C N$ of 90 also was selected for comparison. This refers to Soil Group D, characterized by clay soils with very low infiltration rates. 
The runoff calculations were made by using the equation

$$
\begin{aligned}
& Q=\frac{(P-0.2 S)^{2}}{(P+0.8 S)} \\
& \text { where } S=\text { a retention parameter }(\text { in. })=\frac{1000}{C N}-10 \\
& P=\text { daily rainfall (in.), and } \\
& Q=\text { daily runoff (in.) }
\end{aligned}
$$

Results of the runoff calculations for 1984, shown in Table 5 , provide an estimated annual runoff of 3 inches. Runoff from clay soils, however, with a yield of 15 inches, could produce considerable surface erosion. The extensive gulley development of F-Area Effluent stream may have been caused by similarly increased runoff from the parking lots prior to 1978 .

Table 5 also shows the runoff estimated for Four Mile Creek, using cumulative flow frequency curves for Four Mile Creek described by Hubbard and Emslie. 1 Total surface runoff in that wellvegetated watershed was 1.5 inches in 1984 .

In the study of McQueen Branch, Parizek and Root 3 analyzed stream gage hydrographs to separate surface runoff from base flow. About 2 inches average runoff occurs annually in that watershed, as shown in Table 3 .

\section{Infiltration studies}

Â single-ring infiltrometer was constructed from a section of Shelby tube, rubber stopper rings, and a section of glass tubing inserted into the Shelby tube. The apparatus was implanted into the ground and filled with water. The rate of movement into the ground was observed as infiltration took place.

In three scouting measurements made at the burial ground site, the lowest rate observed was about 3 inches per hour. In another measurement the rate was 8 inches per hour, and in the tritium control lysimeter 3 inches of ponded water infiltrated the surface in 20 minutes. Further infiltration measurements should involve more sophistocated tools, such as rainfall simulators like those used by the U. S. Department of Agriculture, or other devices that can be fabricated. 
The thesis by Gruber 7 presents data on soil-water movement in an area of natural soil just west of the burial ground. Several days were required for ponded water in this area to reach a steady rate of infiltration, 0.9 inches per hour. This rate may simply reflect the hydraulic conductivity of a least-permeable layer of the soil horizons 10 feet below the land surface.

Most of the burial ground area soils have high rates of infiltration. However, clay soils brought to the surface in burial ground activities can be considerably less permeable. The contrast between Class $A$ and Class $D$ soils, described in the discussion on runoff and in Table 5, is considerable. At the Chem-Nuclear burial trench site in Barnwell, trench caps are made from clays excavated from the trenches. Runoff amounts in those areas can be fairly large and are being measured by diversion into a surveyed basin (V. Ischamura, personal communication).

\section{Hydrologic Properties of Burial Ground Soils}

The behavior of water in the earth materials below the burial ground involves saturated flow, unsaturated flow, and storage in the soil pores. The heterogeneous nature of the soils and geologic formations must be considered in any analysis. The work by Gruber 7,8 , shows laboratory analyses of cores including a trench core from the site. Figure 3 presents the means, taken from curves presented in the thesis, 7 of the fraction of soil volume filled with water in relation to soil moisture tensions.

The mean moisture content of saturated soils is slightly less than 50\%. The moisture tension represented by $25 \mathrm{~mm} \mathrm{Hg}$ would be unsaturation at field capacity, and perhaps that at $75 \mathrm{~mm} \mathrm{Hg}$ would be representative of wilting point. Because hydraulic conductivity is a function of soil moisture tensions, these data may be useful for modeling. The difference in void space between saturation and field capacity appears to be about 10 per cent. Saturated flow of large amounts of rainfall infiltrating the soils may be rapid through large voids in the earth materials.

\section{RECOMMENDATIONS}

1. Water balance studies utilizing the lysimeters should be continued, particularly if the leaking lysimeters identified can be easily repaired. Rainfall measurements should be supplemented by those from the rain gage installed at the Tank 24 Saltstone Lysimeter station. The format for analyzing hydraulic data from the lysimeters, set up on the SRP computer system by R. Emslie, should be maintained. 
2. The method of forecasting water table elevations in the burial ground area should be examined further, using a network of wells in recharge areas. The method, described in section 2 and Figure 1, may be useful with respect to areas with different soils and vegetative cover.

3. The tracer study noted in section 1 should provide some insight into water movement through earth materials at the burial ground and should be repeated after analysis of this trial to determine the flow paths from surface to sump.

4. With additional development in areas near the burial ground site, McQueen Branch watershed should be gaged regularly, and the data should be related to rainfall, surface flow, and shallow groundwater flow.

5. The U. S. Department of Agriculture Research Service developed a CREAMS model to predict runoff, erosion, and chemical transport. This model should be investigated for potential applications at SRP.

JEH : JAS/tyb

$D:$ JAS 24 


\section{REFERENCES}

1. J. E. Hubbard and R. E. Emslie. "Water Budget for SRP Burial Ground Area." DPST-83-742, March 19, 1984.

2. R. E. Emslie. "SRP Waste Lysimeters: Hydraulic Performance Through 1982." October 5, 1983.

3. R. R. Parizek and R. W. Root. "Progress Toward the Development of a Ground-Water Velocity Model for the Radioactive Waste Management Facility, Savannah River Plant, South Carolina. Quarterly Report, July 15, 1984." Pennsylvania State University, July 15, 1984.

4. R. Denehy and P. McMahon. "Hydrologic and Micrometeorological Data for an Unsaturated zone Flow study at a Low-Level Radioactive Waste Burial Site, Barnwell, South Carolina." U. S. Geological Survey Open File Report OF85-476.

5. U. S. Geological Survey. "Water Resources Data - South Carolina." USGS Data Report SC-83-1.

6. L. J. Lane. "Surface Water Management: A Users Guide to Calculate a Water Balance Using the CREAMS Model." LA-10177-M, Los Alamos National Laboratory, 1984.

7. Paul Gruber. "A Hydrologic Study of the Unsaturated zone Adjacent to a Radioactive-Waste Disposal Site at the Savannah River Plant, Aiken, South Carolina." Unpublished Masters Thesis, University of Georgia, 1980.

8. P. G. Gruber. "A Hydrologic Study of the Unsaturated Zone Adjacent to a Radioactive-Waste Disposal. Site at the Savannah River Plant, Aiken, South Carolina," pp. 255-287 in Role of the Unsaturated Zone in Radioactive and Hazardous Waste Disposal. J. W. Mercer, P. S. C. Rao, and I. W. Marine (eds.) Ann Arbor Science Publishers, Ann Arbor, MI. 1984. 
TABLE 1

EVAPOTRANSPIRATION ESTIMATE BY LYSIMETER WATER BALANCE*

Water Buaget Components (Inches)

1980-84 Means, (8Annual), (Standard Deviations)

\begin{tabular}{|c|c|c|c|c|c|c|c|c|c|}
\hline \multirow{2}{*}{$\begin{array}{l}\text { Time } \\
\text { Periods } \\
\text { Jan. - Mar. } \\
\text { Apr. - Jun. } \\
\text { Jul. - Sep. } \\
\text { Oct. - Dec. }\end{array}$} & \multicolumn{3}{|c|}{$\begin{array}{c}\text { Rainfall } \\
\mathrm{P}\end{array}$} & \multicolumn{3}{|c|}{$\begin{array}{c}\text { Infiltration } \\
\text { SR+Rx }\end{array}$} & \multicolumn{3}{|c|}{$\begin{array}{c}\text { Evapotranspiration } \\
\text { ET }\end{array}$} \\
\hline & $\begin{array}{r}14.4 \\
11.9 \\
13.2 \\
7.5\end{array}$ & $\begin{array}{l}(318) \\
(258) \\
(288) \\
(168)\end{array}$ & $\begin{array}{l}(3.7) \\
(4.5) \\
(3.4) \\
(2.5)\end{array}$ & $\begin{array}{l}7.5 \\
6.4 \\
2.9 \\
2.8\end{array}$ & $\begin{array}{l}(388) \\
(338) \\
(158) \\
(148)\end{array}$ & $\begin{array}{l}(2.7) \\
(4.3) \\
(2.0) \\
(1.8)\end{array}$ & $\begin{array}{r}6.9 \\
5.5 \\
10.4 \\
4.7\end{array}$ & $\begin{array}{l}(258) \\
(208) \\
(388) \\
(178)\end{array}$ & $\begin{array}{l}(1.1) \\
(1.6) \\
(1.8) \\
(1.7)\end{array}$ \\
\hline \multirow[t]{2}{*}{$\overline{\text { Annual Total }}$} & $\overline{47.0^{\prime \prime}}$ & & $\overline{(7.6)}$ & $19.6^{\prime \prime}$ & & $(4.5)$ & $27.4^{11}$ & & $\overline{(4.5)}$ \\
\hline & \multicolumn{3}{|c|}{1980} & \multicolumn{3}{|c|}{1981} & \multicolumn{3}{|c|}{1982} \\
\hline Period & P & $S R+R x$ & ET & $\mathrm{P}$ & $S R+R x$ & ET & $\mathrm{P}$ & $\underline{S R+R x}$ & ET \\
\hline $\begin{array}{l}\text { Jan. - Mar. } \\
\text { Apr. - Jun. } \\
\text { Jul. - Sep. } \\
\text { Oct. - Dec. }\end{array}$ & $\begin{array}{r}17.3 \\
7.1 \\
9.3 \\
4.7\end{array}$ & $\begin{array}{r}10.0 \\
4.0 \\
1.3 \\
1.6\end{array}$ & $\begin{array}{l}7.3 \\
3.1 \\
8.0 \\
3.1\end{array}$ & $\begin{array}{r}8.5 \\
12.2 \\
11.1 \\
7.9\end{array}$ & $\begin{array}{l}3.3 \\
5.6 \\
1.4 \\
4.9\end{array}$ & $\begin{array}{l}5.2 \\
6.6 \\
9.7 \\
3.0\end{array}$ & $\begin{array}{r}13.4 \\
10.7 \\
18.4 \\
8.6\end{array}$ & $\begin{array}{l}6.7 \\
3.3 \\
5.8 \\
2.4\end{array}$ & $\begin{array}{l}6.7 \\
7.4 \\
9.7 \\
6.2\end{array}$ \\
\hline \multirow[t]{2}{*}{ Annual } & $\overline{38.4}$ & 16.9 & 21.5 & 39.7 & 15.2 & 24.5 & 51.1 & 18.2 & 32.9 \\
\hline & \multicolumn{3}{|c|}{1983} & \multicolumn{3}{|c|}{1984} & \multicolumn{3}{|c|}{1985} \\
\hline Period & $\underline{P}$ & $S R+R x$ & ET & $\mathrm{P}$ & $S R+R x$ & ET & $\underline{P}$ & $S R+R x$ & ET \\
\hline $\begin{array}{l}\text { Jan. - Mar. } \\
\text { Apr. - Jun. } \\
\text { Jul. - Seq. } \\
\text { Oct. - Dec. }\end{array}$ & $\begin{array}{l}17.6 \\
10.4 \\
13.4 \\
10.9\end{array}$ & $\begin{array}{l}9.5 \\
5.1 \\
1.9 \\
4.4\end{array}$ & $\begin{array}{r}8.1 \\
5.3 \\
11.5 \\
6.5\end{array}$ & $\begin{array}{r}15.2 \\
19.2 \\
14.0 \\
5.3\end{array}$ & $\begin{array}{r}8.2 \\
13.9 \\
4.0 \\
0.8\end{array}$ & $\begin{array}{r}7.0 \\
5.3 \\
10.0 \\
4.5\end{array}$ & $\begin{array}{r}11.4 \\
7.4\end{array}$ & $\begin{array}{l}6.0 \\
4.6\end{array}$ & $\begin{array}{l}5.4 \\
2.8\end{array}$ \\
\hline innual & 52.3 & 20.9 & $\overline{31.4}$ & 53.7 & 26.9 & 20.0 & & & \\
\hline
\end{tabular}

* a. SRP unsaturated wasteform lysimeters; data provided by R. Emslie. Analysis by plotting cumulative percolate of nondeviant lysimeters.

b. Precipitation (P) as rainfall was recorded at the burial ground. Runoff and Groundwater Recharge ( $S R+R x$ ) infiltrated the lysimeters, percolated 10 feet, and was pumped from the lysimeter sumps. Evapotranspiration (ET) was taken as the difference, $P-(S R+R X)$. 
TABLE 2

FNAPOTRANSPIRATION ESTIMATE BY EVAPORATION PAN METHOO*

\begin{tabular}{|c|c|c|c|c|c|c|}
\hline \multirow[b]{2}{*}{ Month } & \multirow[b]{2}{*}{$\begin{array}{l}\text { Pan } \\
\text { Coeff. }\end{array}$} & \multicolumn{2}{|c|}{$\begin{array}{l}\text { Actual Pan } \\
\text { Evaporation } \\
\text { (inches) }\end{array}$} & \multicolumn{3}{|c|}{$\begin{array}{l}\text { Estimated ET } \\
\text { (inches) }\end{array}$} \\
\hline & & 1983 & 1984 & $\overline{1983}$ & 1984 & Mean \\
\hline $\begin{array}{l}\text { January } \\
\text { February } \\
\text { March } \\
\text { April } \\
\text { May } \\
\text { June } \\
\text { July } \\
\text { August } \\
\text { September } \\
\text { October } \\
\text { November } \\
\text { December }\end{array}$ & $\begin{array}{l}1.02 \\
0.83 \\
0.65 \\
0.52 \\
0.46 \\
0.52 \\
0.60 \\
0.56 \\
0.47 \\
0.55 \\
0.81 \\
1.02\end{array}$ & $\begin{array}{l}1.40 \\
2.38 \\
4.28 \\
5.14 \\
7.18 \\
7.42 \\
8.20 \\
7.51 \\
5.27 \\
3.94 \\
2.72 \\
1.38\end{array}$ & $\begin{array}{l}1.93 \\
3.05 \\
5.20 \\
5.10 \\
6.96 \\
7.90 \\
7.02 \\
6.15 \\
4.92 \\
4.20 \\
2.73 \\
2.00\end{array}$ & $\begin{array}{l}1.43 \\
1.98 \\
2.78 \\
2.67 \\
3.30 \\
3.86 \\
4.92 \\
4.21 \\
2.48 \\
2.17 \\
2.20 \\
1.41\end{array}$ & $\begin{array}{l}1.97 \\
2.53 \\
3.38 \\
2.65 \\
3.20 \\
4.11 \\
4.21 \\
3.44 \\
2.31 \\
2.31 \\
2.21 \\
2.04\end{array}$ & $\begin{array}{l}1.70 \\
2.26 \\
3.08 \\
2.66 \\
3.25 \\
3.98 \\
4.56 \\
3.82 \\
2.40 \\
2.24 \\
2.20 \\
1.72\end{array}$ \\
\hline Total & & 56.82 & 57.16 & 33.41 & 34.36 & 33.87 \\
\hline
\end{tabular}

* Pan evaporation data were obtained from the South Carolina Edisto Agricultural and Educational Center at Blackville. Pan Coefficients were developed from watershed studies at the U. S. Department of Agriculture Agricultural Research Service Experiment Station at Tifton, Georgia.

\section{TABLE 3}

WATER BUDGET FOR MCQUEEN BRANCH WATERSHED*

Component

Precipitation
Evapotranspiration
Surface Runoff - H Area
Surface Runoff - Basin
Base flow
Groundwater storage

\begin{abstract}
Percentage of Rainfall
\end{abstract}

Average Year (Inches)

$\begin{array}{rr} & 47.72 \\ 63.9 & 30.53 \\ 2.5 & 1.19 \\ 4.3 & 2.05 \\ 22.6 & 10.80 \\ 6.6 & 3.15\end{array}$

* From reference 3. 
TABLE 4

RAINFALC AND STREAMFLOW FOR FOUR SITES NEAR THE BURIAL GROUND FOR WATER YEAR 1983-1984*

\begin{tabular}{|c|c|c|c|c|c|}
\hline \multirow[b]{2}{*}{ Month } & \multirow[b]{2}{*}{$\begin{array}{l}\text { Rainfall } \\
\text { (inches) }\end{array}$} & \multicolumn{4}{|c|}{ Streamflow (inches per month) } \\
\hline & & $\begin{array}{l}\text { McQueen } \\
\text { Branch }\end{array}$ & $\begin{array}{l}\text { Four } \\
\text { Mile }\end{array}$ & $\begin{array}{c}\text { Upper ? } \\
\text { Road } \\
\text { C }\end{array}$ & $\begin{array}{c}\text { Runs at } \\
\text { Road } \\
\text { A }\end{array}$ \\
\hline $\begin{array}{l}\text { April } 1983 \\
\text { May } \\
\text { June } \\
\text { July } \\
\text { August } \\
\text { September } \\
\text { October } \\
\text { November } \\
\text { December } \\
\text { January } 1984 \\
\text { February } \\
\text { March }\end{array}$ & $\begin{array}{l}4.71 \\
2.33 \\
3.66 \\
2.94 \\
4.68 \\
4.62 \\
1.64 \\
5.16 \\
2.89 \\
2.73 \\
5.15 \\
6.77\end{array}$ & $\begin{array}{l}1.48 \\
1.07 \\
0.79 \\
0.65 \\
1.05 \\
0.84 \\
0.76 \\
1.26 \\
1.08 \\
1.16 \\
1.50 \\
2.16\end{array}$ & $\begin{array}{l}1.96 \\
0.94 \\
0.50 \\
0.18 \\
0.24 \\
0.70 \\
0.08 \\
0.28 \\
0.79 \\
1.73 \\
2.08 \\
2.31\end{array}$ & $\begin{array}{l}1.64 \\
1.23 \\
1.13 \\
0.97 \\
0.91 \\
1.19 \\
1.03 \\
1.31 \\
1.43 \\
1.37 \\
1.53 \\
1.66\end{array}$ & $\begin{array}{l}2.10 \\
1.25 \\
1.11 \\
0.94 \\
0.89 \\
1.15 \\
1.00 \\
1.43 \\
1.57 \\
1.52 \\
1.68 \\
2.00\end{array}$ \\
\hline Total & 47.28 & 13.80 & 11.79 & 15.40 & 16.64 \\
\hline \multicolumn{6}{|c|}{$\begin{array}{l}\text { * Rainfall and McQueen Branch streamf low are from reference 3, } \\
\text { Table 5. Streamflow data for Four Mile Creek and Upper } \\
\text { Three Runs Creek recorded by the U. S. Geological Survey } \\
\text { were converted from cubic feet per second to area inches per } \\
\text { month. The drainage areas and estimated elevations above } \\
\text { sea level are: }\end{array}$} \\
\hline \multicolumn{2}{|c|}{ MCQueen Branch at weir } & \multicolumn{4}{|c|}{4.4 square miles; 170 feet $\mathrm{msl}$. } \\
\hline \multicolumn{2}{|c|}{ Four Mile Creek at Road 4: } & \multicolumn{4}{|c|}{5.9 square miles; 205 feet $\mathrm{msl}$. } \\
\hline \multicolumn{2}{|c|}{ Upper Three Runs at Road C: } & C: $\quad 176$ & are mi & \multicolumn{2}{|c|}{130 feet $\mathrm{msl}$. } \\
\hline \multicolumn{2}{|c|}{ Upper Three Runs at Road A: } & A: $\quad 203$ & e $m$ & $120 f$ & \\
\hline
\end{tabular}


TABLE 5

COMPARATIVE ESTIMATES OF SURFACE RUNOFE IN 1984:

COMPARING THE USDA METHOD OF ANALYSIS WITH

THE CUMULATIVE FLOW FREQUENCY METHOD*

\begin{tabular}{|c|c|c|c|c|}
\hline Month & $\begin{array}{c}\text { Precipitation } \\
\text { at } 200 \mathrm{~F} \text { Area, } \\
\text { in. }\end{array}$ & $\begin{array}{l}\text { Runoff by } S \\
\text { Case } A \text {, } \\
\text { in. (\# days) }\end{array}$ & $\begin{array}{l}5 \text { Method } \\
\text { Case D, } \\
\text { in. (\# days) }\end{array}$ & $\begin{array}{l}\text { Runoff by } \\
\text { Cumulative } \\
\text { Elow Freq. } \\
\text { Analysis, } \\
\text { in. (\# days) }\end{array}$ \\
\hline $\begin{array}{l}\text { Jan. } \\
\text { Feb. } \\
\text { Mar. } \\
\text { Apr. } \\
\text { May } \\
\text { Jun. } \\
\text { Jul. } \\
\text { Aug. } \\
\text { Sep. } \\
\text { Oct. } \\
\text { Nov. } \\
\text { Dec. }\end{array}$ & $\begin{array}{r}3.54 \\
5.34 \\
6.05 \\
7.11 \\
10.73 \\
1.82 \\
6.46 \\
3.53 \\
1.06 \\
0.40 \\
0.97 \\
1.16\end{array}$ & $\begin{array}{ll}0.00 & \\
0.65 & (3) \\
0.21 & (1) \\
0.37 & (3) \\
1.42 & (5) \\
0.00 & \\
0.04 & (1) \\
0.47 & \text { (1) } \\
0.00 & \\
0.00 & \\
0.00 & \\
0.00 & \end{array}$ & $\begin{array}{ll}0.61 & (4) \\
2.68 & (3) \\
1.68 & (7) \\
2.27 & (6) \\
5.29 & (7) \\
0.10 & (2) \\
1.35 & (9) \\
1.49 & (1) \\
0.20 & (1) \\
0.02 & (1) \\
0.03 & (1) \\
0.06 & (2)\end{array}$ & $\begin{array}{ll}0.04 & (2) \\
0.24 & (4) \\
0.08 & (2) \\
0.32 & (5) \\
0.39 & (2) \\
0.05 & (2) \\
0.17 & (4) \\
0.20 & (2) \\
0.00 & \\
0.00 & \\
0.00 & \\
0.00 & \end{array}$ \\
\hline Total & 48.17 & $3.16(14)$ & $15.78(44)$ & $1.49(23)$ \\
\hline
\end{tabular}


FIGURE 1

GROUNDWATER RECHARGE AND WATER TABLE ELEVATION 1980-1985

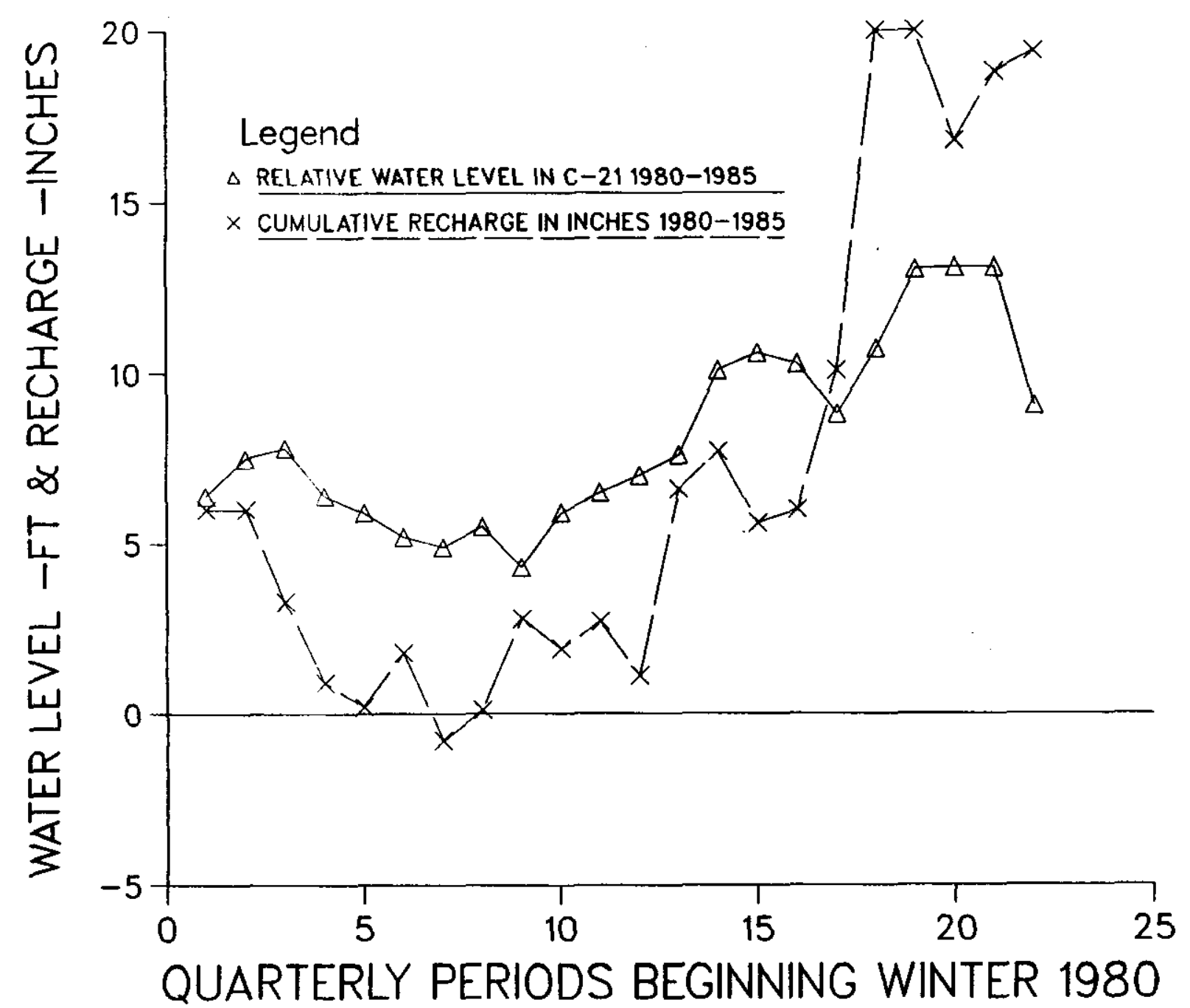


E. I. ALBENESIUS

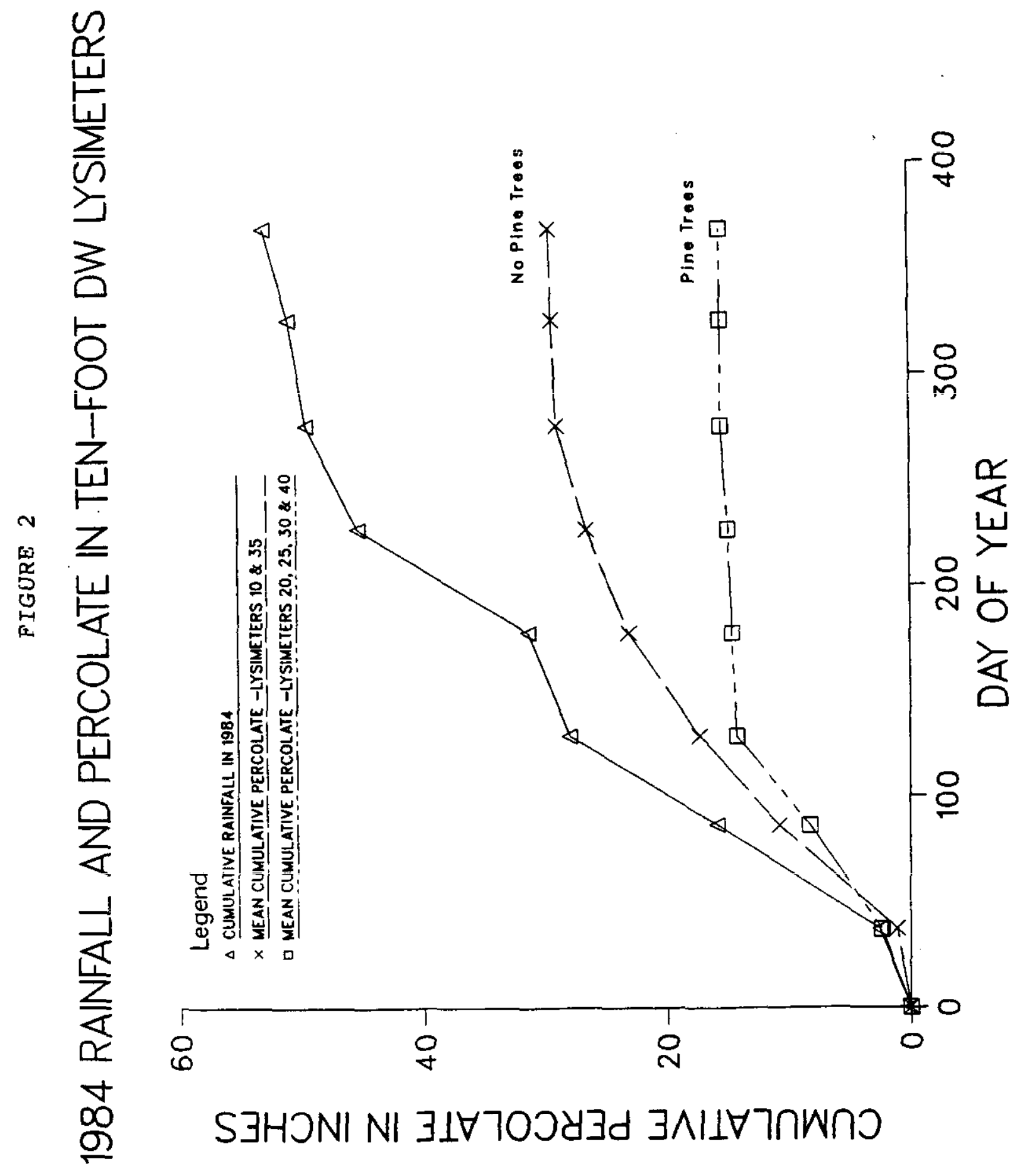


FIGURE 3

MEAN SOIL-WATER CHARACTERISTIC CURVE FOR TRENCH SOIL CORES

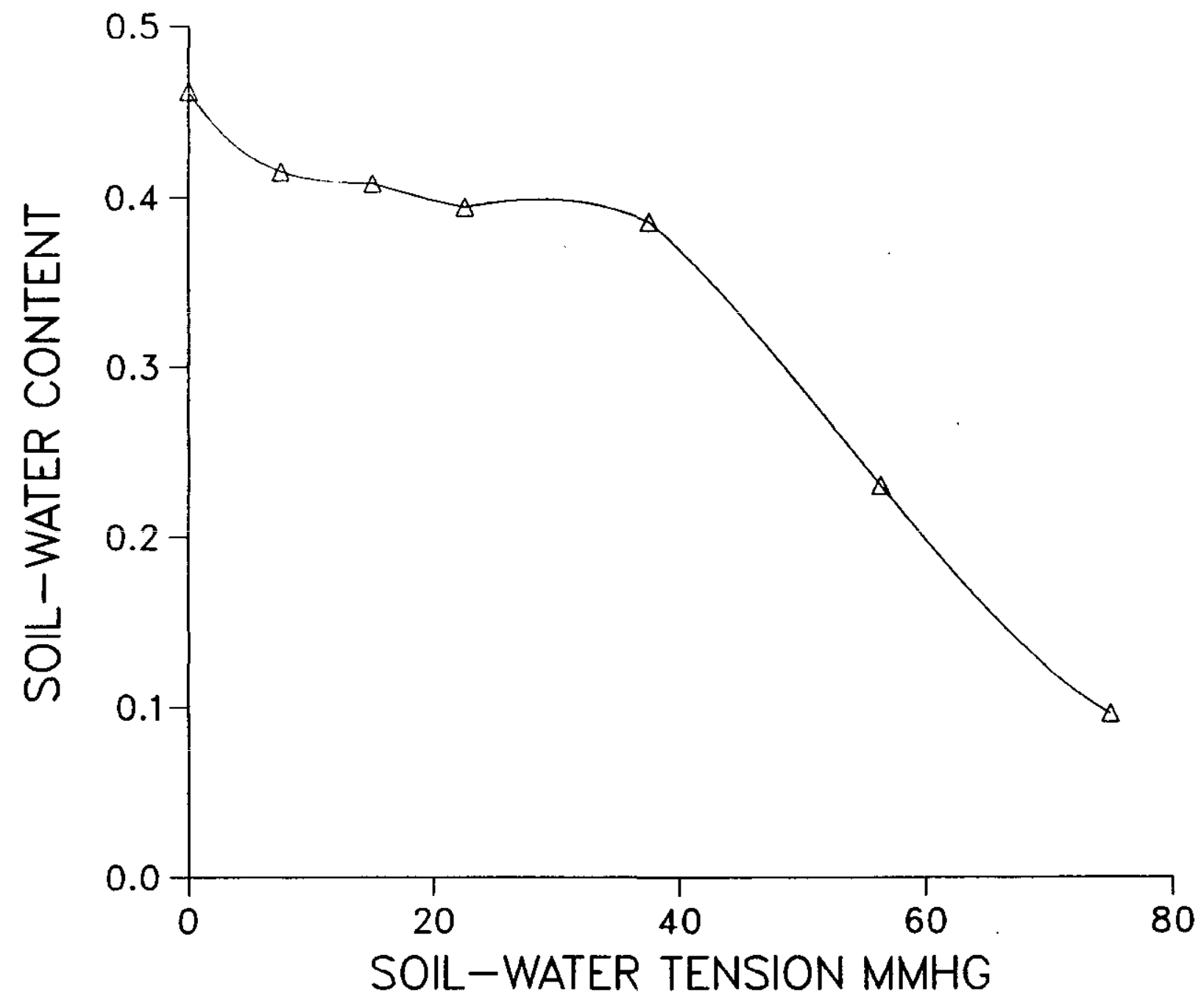

0
0
0
7
1
$\infty$
0
1
0
w
$\infty$ 